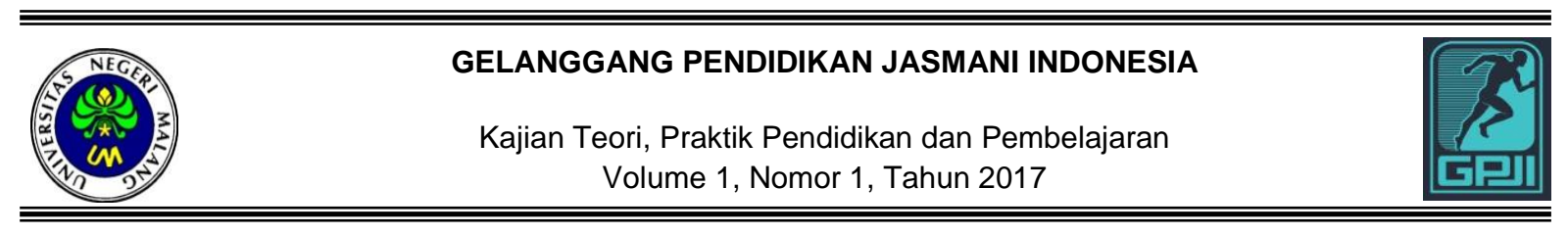

\title{
PENGARUH LATIHAN DISTRIBUTED PRACTICE TERHADAP KETERAMPILAN PASSING BAWAH BAGI PESERTA EKSTRAKURIKULER BOLAVOLI SMA NEGERI 10 MALANG
}

\author{
Candra Junianto \\ M. E. Winarno \\ Sugiyanto \\ Fakultas Ilmu Keolahragaan Universitas Negeri Malang \\ Email: Juniantocandra06@gmail.com
}

\begin{abstract}
This research was conducted in order to determine the difference between the effect of exercise distributed practice and conventional excercise against passing skills down on extracurricular participants volleyball SMAN 10 Malang. This research used experimental research design pretest posttest control group design. Subjek much as 20 participants extracurriculer volleyball SMAN 10 Malang. Analysis of the data used in this study is in the form of analytical techniques paired sample $t$ test and variance test one way. Based on the results of data analysis showed that there was no difference between the effects of exercise distributed practice and conventional exercise against passing skills down extracurricular volleyball volleyball participants in SMAN 10 Malang to generate significant value of $\mathrm{F} 0.349$ and $0.562>0.05$.
\end{abstract}

Keywords: volleyball's game, distributed practice, volleyball's under passing

\begin{abstract}
Abstrak: Penelitian ini dilaksanakan dengan tujuan untuk mengetahui perbedaan pengaruh latihan distributed practice dan latihan konvensional terhadap keterampilan passing bawah pada peserta ekstrakurikuler bolavoli SMAN 10 Malang. Penelitian ini menggunakan rancangan penelitian eksperimen pretest posttest control group design. Subjek sebanyak 20 peserta ekstrakurikuler bolavoli SMAN 10 Malang. Analisis data yang digunakan yaitu berupa teknik analisis paired sample $t$ test dan uji varians satu jalur. Berdasarakan hasil analisis data menunjukkan bahwa tidak ada perbedaan pengaruh antara latihan distributed practice dan latihan konvensional terhadap keterampilan passing bawah bolavoli pada peserta ekstrakurikuler bolavoli di SMAN 10 Malang dengan menghasilkan Fhitung 0,349 dan nilai signifikasi 0,562>0,05.
\end{abstract}

Kata Kunci: permainan bolavoli, distributed practice, passing bawah bolavoli

Olahraga merupakan bagian dari salah satu usaha untuk membangun bangsa dan negara dalam membina individu-individu yang sehat dan kuat baik fisik maupun mental spiritual. Melalui olahraga diharapkan dapat terbina suatu sikap dan mentalitas yang dapat diarahkan pada toleransi dan tanggung jawab yang mengarah pada persatuan dan ke-satuan diantara individu-individu yang terlibat didalamnya baik langsung maupun tidak langsung. Pada era sekarang ini olahraga sudah menjadi kebutuhan dan seringkali dilakukan sebagai kegiatan yang berguna untuk membina jasmani dalam rangka memperoleh kebugaran dan kesehatan. Kegiatan olahraga juga dijadikan sebagai kegiatan manusia untuk saling berinteraksi dan bersosialisasi satu sama lain dan bahkan dijadikan se-bagai ajang untuk berprestasi.

Di indonesia terdapat banyak cabang olahraga yang dikenal oleh masyarakat semua kalangan. Salah satu cabang olahraga yang cukup dikenal dan digemari oleh masyarakat Indonesia adalah olahraga permainan bolavoli. Permainan bolavoli cukup digemari dan dimainkan banyak orang karena didalam permainan ini selain para 
Candra Junianto, Pengaruh Latihan Distributed Practice Terhadap Keterampilan Passing Bawah Bagi Peserta Ekstra-kurikuler Bolavoli SMA Negeri 10 Malang

pemain dituntut untuk menguasai teknikteknik dasar para pemain juga harus bisa saling berkoordinasi dan bekerjasama untuk dapat memenangkan dalam per-mainan. Permainan bolavoli merupakan cabang olahraga beregu yang dimainkan oleh enam orang beregu. Permainan ini akan berjalan dengan baik apabila setiap pemain minimal telah menguasai teknik dasar bermain bolavoli (Sugiyono, 1996:42). Menurut Suharno (1991:1) menyatakan bahwa "permainan bolavoli adalah olahraga beregu yang dimain-kan oleh dua regu, masingmasing regu terdiri dari enam orang pemain di lapangan permainan yang berukuran $18 \mathrm{~m}$ x 9 m."

Di lingkungan sekolah pembinaan olahraga dapat dilakukan melalui kegiatan ekstrakurikuler. Tujuan dari kegiatan ekstrakurikuler adalah mengembangkan keterampilan yang dimiliki siswa secara maksimal untuk memenangkan suatu pertandingan yang dihadapi. Melalui kegiatan ekstrakurikuler ini akan terbentuk tim olahraga dari suatu sekolah sesuai dengan cabang olahraga tertentu (Mu'arifin, 2009:64). Tugas utama sekolah adalah mendidik peserta. Artinya tidak semata-mata menja-dikan mereka pintar dan terampil, tetapi juga harus mampu menumbuh kembang-kannya menjadi pribadi yang sehat jasmani dan rohani, sadar dan ber-tanggungjawab akan keberadaan dirinya baik sebagai pribadi sebagai makhluk Tuhan Yang Maha Esa mau-pun sebagai makhluk sosial yang merupakan bagian tak terpisahkan dari lingkungannya. Menurut Prihatin (2011: 170) menjelaskan bahwa "kegiatan pengembangan diri harus memper-hatikan prinsip individu. Secara psikologis, setiap siswa memiliki kebutuhan, bakat dan minat serta karakteristik lainnya yang beragam. Oleh karena itu, bentuk pengembangan diripun seyog-yanya dapat menyediakan beragam pilihan. Hal yang fundamental dalam kegiatan pengembangan diri bahwa pelaksanaan pengembangan diri harus terlebih dahulu diawali dengan upaya untuk mengidentifikasi kebutuhan, ba-kat dan minat yang dapat dilakukan melalui teknik tes (tes kecerdasan, tes bakat, tes minat dan sebagainya) maupun non tes (skala sikap, inventori, observasi, studi dokumen-ter, wawan-cara dan sebagainya)." Kegiatan ekstrakurikuler merupakan suatu kegiatan yang dilaksanakan oleh suatu sekolah dimana kegiatan ini menjadi wadah khusus bagi siswa untuk menyalurkan bakat dan minat guna memperluas pengetahuan dari masing-masing se-tiap individunya. Menurut Prihatin (2011:160) "jenis-jenis kegiatan ekstra-kurikuler yaitu: a) pramuka sekolah, b) olahraga dan kesenian, c) kebersihan dan keamanan sekolah, d) tabungan pelajar dan pramuka (tapelpram), e) majalah sekolah, f) warung/kantin sekolah, g) usaha kesehatan sekolah.

Pengamatan yang dilakukan pene-liti terhadap salah satu kegiatan ekstrakurikuler di SMA Negeri 10 Malang yaitu kegiatan ekstrakurikuler bolavoli ketika menjalankan Kajian Praktik Lapangan (KPL) pada bulan September sampai Oktober 2015 melalui observasi pada kegiatan tersebut menemukan bahwa kemampuan atlet dalam melakukan keterampilan teknik dasar per-mainan bolavoli masih terlihat kurang menguasai teknik dasar passing ba-wah. Pernyataan tersebut diperkuat peneliti dengan hasil pengamatan terhadap per-mainan bolavoli pada tanggal 25 November 2015 menghasilkan data yang dapat dinyatakan bahwa, kegagalan teknik pas-sing bawah merupakan persentase kega-galan tertinggi dengan jumlah salah 61 kali dengan persentase $(72,61 \%)$ dan jumlah benar sebanyak 23 kali dengan persentase $(27,38 \%)$, diikuti teknik passing atas dengan jumlah salah sebanyak 16 kali dengan persentase $(38,09 \%)$ dan jumlah benar sebanyak 26 kali dengan persentase $(61,90 \%)$, kemudian teknik smash dengan jumlah salah sebanyak 11 kali dengan persentase $(35,48 \%)$ dan jumlah benar sebanyak 20 kali dengan persentase $(64,51 \%)$, kemudian teknik block de-ngan jumlah salah sebanyak 4 kali dengan persentase $(26,66 \%)$ dan jum-lah benar sebanyak 11 kali dengan per-sentase (73,33\%), dan teknik service dengan jumlah salah sebanyak 12 kali dengan persentase (26,08\%) dan jum-lah benar sebanyak 34 kali dengan persentase $(73,91 \%)$. Pengamatan permainan bolavoli ini dilakukan selama 2 set dengan jumlah kemenangan sesuai dengan aturannya yaitu 25 point pada setiap setnya. Dari data tersebut dapat disimpulkan bahwa teknik dasar pass-ing bawah di kegiatan ekstrakurikuler SMA Negeri 10 Malang menjadi kega-galan tertinggi dan solusi untuk 
menyelesaikan masalah tersebut adalah dengan memberikan perlakuan khu-sus pada teknik dasar passing bawah ka-rena pada dasarnya teknik tersebut meru-pakan teknik paling utama yang harus dikuasai oleh seorang pemain dalam per-mainan bolavoli.

Metode latihan yang diberikan oleh pelatih ekstrakurikuler bolavoli di SMA Negeri 10 Malang selama ini hanya dilatih untuk melakukan suatu praktek gerakan latihan secara terus-menerus atau secara kontinyu tanpa adanya pemberian waktu istirahat sehingga peserta mengalami kelelahan. Kesempatan melakukan setiap gerakan yang tidak setara atau tidak sama pada setiap peserta juga menjadi faktor kelemahan yang dialami oleh peserta dalam mengikuti kegiatan ekstrakurikuler bolavoli ini. Kebutuhan akan adanya metode yang efisien dan menunjang untuk latihan keterampilan bermain bolavoli sangat diperlukan terutama dalam menentukan dan me-milih metode latihan yang sesuai. Jika dilihat dari masalah yang muncul maka perlu adanya pendekatan pemberian perlakuan gerak yang sesuai untuk memberikan pengaruh di dalam pe-ningkatan keterampilan passing bawah bolavoli terhadap peserta. Salah satu pendekatan latihan yang dapat meningkatkan kemampuan peserta dalam penguasaan keterampilan passing ba-wah bolavoli adalah dengan memberikan pendekatan latihan distributed practice.

Winarno (1994:8) mengemukakan bahwa "distributed practice adalah prinsip pengaturan giliran dalam latihan dimana diadakan pengaturan waktu untuk latihan dengan waktu untuk istirahat secara berselang-seling. Disini dipertimbangkan waktu untuk istirahat sama pentingnya dengan waktu untuk latihan". Dalam cabang olahraga bolavoli, metode latihan ini dapat digunakan untuk meningkatkan keterampilan pass-ing bawah bolavoli yang tentunya telah disesuaikan dengan kebutuhan. Menurut Sugiyono (1996:125) "Dasar latihan distributed practice adalah peng-gunaan selang istirahat (recovery) dari satu kegiatan ke kegiatan lain dilakukan dengan waktu yang agak panjang (kembali ke kondisi normal)". Distributed practice adalah serangkaian kegiatan latihan melibatkan kegiatan istirahat yang cukup diantara kegiatan mencoba (Lutan, 1988:113). Dari bebe- rapa pendapat para ahli di atas dapat penulis simpulkan bahwa distributed practice merupakan metode latihan yang membuat pengaturan waktu antara proses latihan dan waktu istirahat selama proses latihan berlangsung. Dalam proses kegiatan ini harus benar-benar mempertimbangkan waktu antara latihan dan waktu untuk istirahat karena kedua hal tersebut merupakan prinsip dasar dari metode ini.

Menurut Ahmadi (2007:20) "Permainan bolavoli merupakan suatu permainan yang kompleks yang tidak mudah dilakukan oleh setiap orang. Sebab, dalam permainan bolavoli dibu-tuhkan koordinasi gerak yang benar-benar bisa diandalkan untuk melakukan semua gerakan yang ada dalam permainan bolavoli”. Permainan bola-voli merupakan cabang olahraga beregu yang dimainkan oleh enam orang beregu. Permainan ini akan berjalan dengan baik apabila setiap pemain minimal telah menguasai teknik dasar bermain bolavoli (Sugiyono, 1996:42). Memvoli bola artinya memantulkan bola diudara sebelum jatuh di tanah. Permainan bolavoli adalah olahraga beregu yang dimainkan oleh dua regu, masing-masing regu terdiri dari 6 orang pemain dilapangan permainan yang berukuran $18 \mathrm{~m}$ x $9 \mathrm{~m}$ (Suharno, 1991:1). Menurut Yunus (1992:1) "Pada awalnya ide dasar permainan bolavoli itu adalah memasukkan bola ke daerah lawan mele-wati suatu rintangan berupa tali atau net dan berusaha memenangkan permainan dengan mematikan bola itu di daerah lawan".

Dengan demikian dari beberapa pendapat para ahli dapat penulis simpulkan bahwa pengertian permainan bolavoli adalah sebuah permainan atau olahraga yang dimainkan secara beregu dengan tiap regunya berjumlah enam pemain menggunakan sebuah bola yang setiap regu saling berusaha untuk mendapatkan point dan bisa memenangkan permainan dengan cara memainkan bola yang harus dimainkan melewati atas net agar se-bisa mungkin bola tersebut jatuh di area lapangan lawan. Dalam per-mainan bolavoli ini setiap pemain dalam sebuah regu harus mampu untuk bisa menguasai teknik-teknik dalam permainan ini sendiri dan bisa saling membuat kerjasama regu dalam me-lakukan permainan ini. Permainan bolavoli ini 
Candra Junianto, Pengaruh Latihan Distributed Practice Terhadap Keterampilan Passing Bawah Bagi Peserta

dimainkan di atas lapangan yang memiliki ukuran panjang 18 meter dan lebar 9 meter dan di tengah lapangan terdapat net sebagai salah satu bagian dalam permainan yang memiliki ketinggian tertentu sesuai kebutuhan permainan. Tujuan pemain dalam bermain adalah menjatuhkan bola secepat mungkin dilapangan lawan lewat atas net dengan bagian badan pinggang keatas dengan syarat pantulkan bola bersih sempurna sesuai dengan peraturan. Pantulan dianggap tidak sah apabila bola itu didorong, ditahan dan diangkat (Suharno, 1991:1).

Passing merupakan teknik da-sar yang paling sering frekuensinya digunakan dalam permainan bolavoli. Sehingga teknik passing ini benar-benar harus dikuasai oleh setiap pemain (Winarno dan Sugiyono, 2011: 51). Menurut Yunus (1992:79) "Pas-sing adalah mengoperkan bola kepada teman sendiri dalam satu regu dengan suatu teknik tertentu sebagai langkah awal untuk menyusun pola serangan kepada regu lawan". Menurut Roesdi-yanto (1991: 15) menjelaskan bahwa: "Peranan passing di dalam permainan bolavoli sangat besar sekali, kalau service dapat disebut sebagai serangan pertama untuk teknik passing dapat dikatakan adalah teknik untuk dapat suatu regu bermain menyerang mak-sudnya dengan melakukan passing akan dengan mudah seorang pemain mengarahkan bola semaunya ke arah yang dikehendakinya pada teman seregunya yang nantinya bola tersebut akan dijadikan sebagai sarana serangan terhadap regu lawan". Dari beberapa pendapat para ahli di atas, penulis dapat menyimpulkan bahwa passing merupakan salah satu teknik dasar bermain bolavoli yang harus bisa dikuasai oleh setiap pemain. Teknik ini digunakan untuk mengumpan bola kepada teman satu regu untuk langkah awal menyusun sebuah serangan kepada regu lawan.

Passing bawah akan dilakukan oleh seorang pemain apabila bola yang datang jatuh berada di depan atau samping badan setinggi perut ke bawah. Cara pelaksanaannya sebagai berikut:

Berdiri tegak dengan kaki kangkang selebar bahu, atau lebih lebar sedikit, posisi lutut sedikit ditekuk. Kedua lengan dirapatkan di depan badan dengan kedua lengan dijulurkan lurus ke bawah, siku jangan ditekuk (sudut antara lengan dengan badan $\pm 45^{\circ}$ ) (Winarno dan Sugiyono, 2011:51). Agar pada saat terjadi perkenaan bola tidak lepas maka taruh salah satu tangan di atas telapak tangan yang lain dengan kedua ibu jari berada sejajar dan pegang dengan erat (Winarno dan Sugiyono, 2011:51).

Perkenaan lengan dengan bola berada pada lengan bagian atas pergelangan tangan dan di bawah siku. Ambilah posisi sedemikian rupa sehingga badan berada dalam posisi menghadap pada bola. Begitu bola berada pada jarak yang tepat maka segera ayunkan kedua lengan yang telah diluruskan dari arah bawah ke atas depan. Pada saat itu antara tangan kanan dan tangan kiri sudah saling berpegangan. Antara badan dengan kedua lengan membentuk sudut $\pm 45^{\circ}$ agar bola memantul secara stabil (Winarno dan Sugiyono, 2011:52).

Setelah bola dipassing maka segera diikuti dengan mengambil sikap kembali agar dapat bergerak dengan cepat dan menyesuaikan diri dengan permainan. Lanjutkan gerakan lengan paling tinggi maksimal sejajar (rata) dengan bahu (Winarno dan Sugiyono, 2011:52).

Menurut Durrwachter (1982:54) menjelaskan bahwa "Pemula baru bisa menguasai teknik passing bawah yang tepat dengan lengan bawah dirapatkan setelah berulangkali melatih diri. Apa-bila ada yang mengalami kesulitan karena keadaan anatominya pemain itu sebaiknya mencoba dulu dengan ta-ngan yang direntangkan ke bawah. Dan jangan langsung membiasakan diri pada passing bawah dengan pergelangan tangan atau dengan tangan."

Berikut ini adalah beberapa kondisi yang perlu diperhatikan ber-kaitan dengan keberadaan bola (datangnya bola) oleh pemain pada saat akan melakukan passing bawah: (1) Apabila bola datang setinggi dada atau bahu, maka segera mundur secukupnya sehingga bola diperkirakan akan jatuh di depan badan setinggi sekitar pinggul dan perut. (2) Apabila bola datang setinggi dada dan pinggul, maka pemain tidak perlu bergerak ke depan maupun ke belakang yang penting pemain tersebut harus pandai membaca datangnya bola sehingga dapat menyesuaikan posisi jarak jangkauan sebaik-baiknya. (3) Apabila bola 
datang setinggi lutut ke bawah, maka pemain tersebut harus cepat menyesuaikan diri dengan bergerak ke depan sehingga sebelum bola turun bola tetap dapat di passing dengan perkenaan bola pada tangan diantara pergelangan tangan dan siku.

Pengaturan langkah maju dan mundur serta merendahkan dan meninggikan badan diperlukan dengan tujuan untuk menyesuaikan diri dengan datangnya bola sehingga bola akan mengenai bagian lengan yang lebar dan memperoleh pan-tulan bola yang sempurna (Winarno dan Sugiyono, 2011:53). Beberapa kemung-kinan kesalahan yang terjadi pada saat melakukan passing bawah adalah: (1) Siku ditekuk sehingga perkenaan bola terlalu atas di atas kedua siku (lebih tinggi dari perkenaan yang normal). Bola akan memantul vertikal dan bahkan akan memantul ke belakang. (2) Sudut datang arah bola terhadap lengan tidak tegak lurus, sehingga pantulan bola tidak sempurna. (3) Gerakan ayunan lengan terlalu kuat, sehingga pantulan bola melebihi sasaran yang diinginkan. (4) Lengan tidak lurus dan tidak menegang kuat (kontraksikan otot-otot lengan), se-hingga pantulan bola tidak sampai pada sasaran yang dikehendaki. (5) Per-kiraan pemain terhadap datangnya bola tidak tepat, sehingga pelaksanaan passing bawah tidak sempurna. (6) Lengan pemukul diayun atau digerak-kan lebih tinggi dari bahu (kecuali passing bawah ke belakang). (7) Pada saat perkenaan kedua tangan tidak sejajar dan rapat serta goyah, hal ini berakibat pantulan bola kurang bagus. (8) Terlambat mengantisipasi datang-nya bola, sehingga bola turun terlalu rendah perkenaannya. (9) Terlalu eksplosif gerakan keseluruhan, gerakan statis dan kaku pada saat melakukan passing bawah. (10) Pada saat mela-kukan passing bawah pandangan tidak kearah bola.

Penelitian sejenis sebelumnya per-nah dilakukan oleh Iskandar (2011: 52) dengan judul "Perbedaan Pengaruh Metode Massed Practice Dengan Distributed Practice Terhadap Kemam-puan Pass Atas Bolavoli Yunior Klub Bolavoli Rinex Boyolali". Hasil pene-litian menunjukkan bahwa latihan distributed practice lebih baik daripada latihan massed practice terhadap ke- mampuan pass atas bolavoli pada pemain Yunior Klub Bolavoli Rinex Boyolali. Kemudian penelitian selanjut-nya yang dilakukan oleh Marwan (2009:125), yaitu: "Perbedaan Metode Latihan Distribusi, Latihan Padat dan Motivasi Berprestasi Terhadap Kete-rampilan Bolavoli. Hasil penelitian menunjukkan bahwa latihan distribusi lebih baik daripada yang dilatih dengan latihan padat.

Berdasarkan latar belakang terse-but, maka peneliti ingin melakukan penelitian yang mendalam melalui pe-nelitian eksperimen dengan judul "Pengaruh Latihan Distributed Practice Terhadap Keterampilan Passing Bawah Bagi Peserta Ekstrakurikuler Bolavoli SMA Negeri 10 Malang".

Tujuan dari dilaksanakannya pene-litian ini untuk mengetahui: (1) Penga-ruh latihan distributed practice terhadap keterampilan passing bawah pada peserta ekstrakurikuler bolavoli SMA Negeri 10 Malang. (2) Pengaruh latihan konvensional terhadap keterampilan passing bawah pada peserta ekstra-kurikuler bolavoli SMA Negeri 10 Malang. (3) Perbedaan pengaruh anta-ra latihan distributed practice dan latihan konvensional terhadap keteram-pilan passing bawah pada peserta ekstrakurikuler bolavoli SMA Negeri 10 Malang.

\section{METODE}

Rancangan penelitian yang digu-nakan pada penelitian ini adalah ranca-ngan penelitian yang bersifat eks-perimental semu dengan bentuk "Pretest Posttest Control Group Design". Penggunaan ranca-ngan ini dimaksudkan untuk mengung-kapkan hubungan sebab-akibat dengan cara melibatkan kelompok kontrol disam-ping kelompok eksperimental (Winar-no, 2007:38). Variabel yang diteliti pada penelitian ini berupa (1) variabel bebas, yaitu (a) latihan distributed practice dan (b) latihan konvensional, variabel terikatnya yaitu keterampilan passing bawah bolavoli.

Subjek penelitian yang digunakan dalam penelitian ini adalah 20 peserta ekstrakurikuler bolavoli di SMAN 10 Malang (putra 13 peserta dan putri 7 peserta) dengan menggunakan seluruh anggota populasi yaitu peserta eks-trakurikuler kelas 
Candra Junianto, Pengaruh Latihan Distributed Practice Terhadap Keterampilan Passing Bawah Bagi Peserta

$\mathrm{X}$ dan kelas XI. Pembagian kelompok penelitian ini dilakukan dengan menggunakan teknik ordinal pairing matching (Hadi, 2004: 184) berdasarkan hasil tes awal (pretest) dengan pembagian 10 peserta untuk kelompok eksperimen dan 10 peserta lainnya menjadi kelompok kontrol, sehing-ga kedua kelompok mempunyai kemam-puan yang setara dan seimbang.

Instrumen yang digunakan dalam penelitian ini menggunakan instrumen tes dan non tes. Instrumen tes digunakan untuk pengambilan data pretest dan posttest keterampilan passing bawah bolavoli dari American Association for Health, Physical Education Recreation and Dance (AAHPERD) (Winarno, 2006:27). Tes keterampilan passing bawah ini memiliki validitas 0,86 dan juga memi-liki koefisien reliabilitas tes sebesar tidak kurang dari 0,80 (Winarno, 2006: 28). Instrumen non tes bentuk pengamatan digunakan untuk mengamati pelaksanaan tes diikuti pencatatan sesegera mungkin dan digunakan untuk mengamati pelaksanaan perlakuan selama tes berlangsung.

Tenik pengumpulan data pada penelitian ini menggunakan teknik eksperimen, observasi, dan teknik pengukuran bentuk tes yaitu tes kete-rampilan passing bawah bolavoli dari American Association for Health, Physical Education Recreation and Dance (AAHPERD) (Winarno, 2006: 27). Teknik eksperimen digunakan untuk memberikan perlakuan sebanyak 16 kali pertemuan. Pemberian perlakuan pada kelompok eksperimen berupa latihan keterampilan passing bawah bolavoli menggunakan metode distributed practice dan menggunakan metode latihan konvensional pada kelompok kontrol. Teknik observasi digunakan untuk mengamati arah bola terhadap ketepatan sasaran pada pelaksanaan tes.

Jenis data yang diperoleh dari hasil tes passing bawah ke tembok berupa data rasio. Dengan pertimbangan tujuan pene-litian dan jenis data yang terkumpul tersebut, maka untuk mengetahui ada atau tidaknya pengaruh pemberian latihan passing bawah menggunakan metode distri-buted practice terhadap keterampilan passing bawah bola voli pada peserta ekstra-kurikuler bolavoli SMA Negeri 10 Malang. Data dianalisis dengan meng-gunakan statistic inferencia. Adapun teknik yang digunakan berupa (1)
Uji Paired Sample T Test dan (2) Uji One Way Anova.

Sebelum prosedur analisis data dilakukan, terlebih dahulu dilakukan uji prayarat analisis yaitu uji normalitas dan uji homogenitas. Semua prosedur analisis uji persyaratan yaitu uji nor-malitas dan uji homogenitas dilakukan dengan bantuan jasa komputer program SPSS (Statistical Package for the Social Science) versi 22. Uji normalitas ini digunakan untuk menge-tahui apakah data yang diperoleh berdis-tribusi normal atau tidak. Uji normalitas pada penelitian ini menggunakan teknik onesample kolmogorov-smirnov test (Irianto, 2012:272). Uji homogenitas bertu-juan untuk memastikan bahwa varian dari setiap kelompok sama atau sejenis, sehingga perbandingan dapat dilakukan secara adil (Maksum, 2012: 162). Uji homogenitas penelitian ini menggunakan teknik levene test. Dalam uji homogenitas berlaku ketentuan seperti pada uji normalitas, yakni: jika $p$-value lebih besar dibanding 0,05, maka data dinyatakan homogen. Sebaliknya, jika p-value lebih kecil dibanding 0,05, maka data dinyatakan tidak homogen (Maksum, 2012:163).

\section{HASIL}

Berdasarkan tujuan dan hipo-tesis penelitian yang sudah diterangkan dan data variabel yang diteliti berupa keterampilan passing bawah bolavoli sudah diperoleh hasil datanya, selanjutnya data dianalisis dengan menggunakan skor tes awal (pretest) dan skor tes akhir (postest) keterampilan passing bawah bolavoli pada setiap peserta ekstrakurikuler bolavoli SMA Negeri 10 Malang. Berikut ini hasil data keterampilan passing bawah bolavoli ke tembok yang disajikan dalam tabel 1 .

Tabel 1. Deskripsi Data Keterampilan Passing Bawah ke Tembok Peserta Ekstrakurikuler Bola-voli SMA Negeri 10 Malang

\begin{tabular}{cccc}
\hline \multicolumn{2}{c}{ Data Prestasi } & $\begin{array}{c}\text { Skor } \\
\text { Awal }\end{array}$ & $\begin{array}{c}\text { Skor } \\
\text { Akhir }\end{array}$ \\
\hline \multirow{2}{*}{ Kelompok } & $\mathrm{N}$ & 10 & 10 \\
Latihan & Mean & 28 & 39,9 \\
Distributed & SD & 11,66 & 12,52 \\
Practice & Maks & 50 & 64 \\
& Min & 14 & 23 \\
\hline
\end{tabular}




\begin{tabular}{cccc}
\hline \multicolumn{2}{c}{ Data Prestasi } & $\begin{array}{c}\text { Skor } \\
\text { Awal }\end{array}$ & $\begin{array}{c}\text { Skor } \\
\text { Akhir }\end{array}$ \\
\hline \multirow{4}{*}{ Kelompok } & $\mathrm{N}$ & 10 & 10 \\
Latihan & Mean & 29 & 36,6 \\
Konvensional & SD & 12,05 & 12,45 \\
& Maks & 48 & 58 \\
& Min & 15 & 22 \\
\hline
\end{tabular}

Keterangan:

$\mathrm{N} \quad$ : Jumlah sampel pada setiap kelompok

Mean : Rata-rata skor passing bawah ke tembok

SD : Simpangan baku

Maks : Skor maksimal passing bawah ke tembok

Min : Skor minimal passing bawah ke tembok

Hasil perhitungan yang telah di-lakukan bahwa telah diketahui hasil skor tes awal keterampilan passing bawah ke tembok kelompok latihan distributed practice memiliki skor rata-rata 28, skor standar deviasi sebesar 11,66, dan memiliki rentangan skor sebesar 36. Hasil skor tes akhir keterampilan passing bawah ke tembok kelompok latihan distributed practice memiliki skor rata-rata 39,9, skor standar deviasi sebesar 12,52, dan memiliki rentangan skor sebesar 41.

Hasil skor tes awal keterampilan passing bawah ke tembok kelompok latihan konvensional memiliki skor rata-rata 29, skor standar deviasi sebesar 12,05, dan memiliki rentangan skor sebesar 33. Hasil skor tes akhir kete-rampilan passing bawah ke tembok kelompok latihan konvensional memiliki skor rata-rata 36,6, skor standar deviasi sebesar 12,45 , dan memiliki rentangan skor sebesar 36 .

Dalam pelaksanaan tes awal keterampilan passing bawah ke tembok (pretest) seluruh peserta yang berjumlah 20 peserta mendapatkan kesempatan seba-nyak 2 kali kesempatan untuk melakukan tes dengan dibatasi waktu 1 menit untuk setiap kali kesem-patannya. Skor yang diambil untuk dianalisis lebih lanjut meru-pakan skor terbaik dari perolehan setiap peserta yang melakukan tes sebanyak 2 kali kesempatan. Setelah diperoleh data skor tes awal (pretest) dari seluruh peserta kemudian peserta dibagi menjadi 2 kelom-pok dengan menggunakan teknik ordinal matching pairing sehingga kedua kelompok mempunyai kemampuan yang setara dan seim- bang. Kemudian dari kedua kelompok tersebut masing-masing kelompok di-beri perlakuan yang berbeda selama 16 kali pertemuan dengan kegiatan latihan sebanyak 3 kali dalam perminggunya. Pada akhir perlakuan latihan kedua kelompok tersebut kembali melakukan tes keteram-pilan passing bawah ke tembok yang disebut tes akhir (post-test) dengan prose-dur tes sama seperti melakukan tes awal (pretest). Kemudian selanjutnya data tes akhir (posttest) yang diperoleh digunakan sebagai pembanding pada data tes awal (pretest) untuk dianalisis.

Tujuan uji normalitas adalah untuk mengetahui apakah distribusi sebuah data berdistribusi normal atau ber-distribusi tidak normal. Uji normalitas dalam penelitian ini menggunakan uji one-sample Kolmogorovsmirnov test pada taraf signifikansi $\alpha=0,05$. Jika taraf signifikasi dalam uji one-sample Kolmogorov-smirnov test lebih besar dari 0,05 maka data dinyatakan ber-distribusi normal. Hasil perhitungan uji normalitas dengan one-sample kolmo-gorov-smirnov test pada tes awal (pretest) untuk kelompok latihan dis-tributed practice diperoleh nilai statistik sebesar 0,525 dengan nilai signifikasi sebesar 0,946. Nilai perhitungan uji normalitas pada tes akhir (posttest) untuk kelompok latihan distributed practice diperoleh nilai statistik sebesar 0,481 dengan nilai signifikasi sebesar 0,975 . Hasil perhitungan uji normalitas pada tes awal (pretest) untuk kelompok latihan konvensional diperoleh nilai statistik sebesar 0,545 dengan nilai signifikasi sebesar 0,928. Dan hasil perhitungan uji normalitas pada tes akhir (posttest) untuk kelompok latihan konvensional diperoleh nilai statistik sebesar 0,578 dengan nilai signifikasi sebesar 0,892. Dari hasil perhitungan uji normalitas tes awal (pretest) mau-pun tes akhir (posttest) masing-masing kelompok diperoleh nilai signifikasi yang lebih besar dari taraf signifikasi 0,05, maka dapat disimpulkan bahwa semua data untuk masing-masing kelompok berdistribusi normal.

Pengujian homogenitas adalah pengujian mengenai sama tidaknya variansivariansi dua distribusi atau lebih. Untuk menentukan homogen atau tidaknya data adalah dengan membandingkan hasil signifikasi de-ngan taraf signifikasi 0,05 . Jika nilai 
Candra Junianto, Pengaruh Latihan Distributed Practice Terhadap Keterampilan Passing Bawah Bagi Peserta Ekstra-kurikuler Bolavoli SMA Negeri 10 Malang

signifikasi dalam uji Levene Statistic lebih besar dari 0,05, maka data ter-sebut memiliki variansi yang bersifat homogen. Hasil perhitungan uji homo-genitas perbandingan varians antara tes awal (pretest) dan tes akhir (post-test) untuk kelompok dengan latihan distributed practice diperoleh nilai uji levene statistic sebesar 0,10 dengan nilai signifikasi sebesar 0,922. Dan uji homogenitas untuk perbandingan va-rians antara tes awal (pretest) dan tes akhir (posttest) untuk kelompok latihan konvensional diperoleh nilai uji levene statistic sebesar 0,13 dengan nilai sig-nifikasi sebesar 0,911. Dari hasil per-hitungan uji homogenitas masingma-sing kelompok latihan diperoleh nilai signifikasi yang lebih besar dari taraf signifikasi 0,05, maka dari itu dapat disimpulkan bahwa data untuk masing-masing kelompok tersebut variansi populasi menunjukkan homogen.

Setelah dilakukan uji persyaratan analisis varians, yaitu uji normalitas dan uji homogenitas serta didapatkan hasil bahwa seluruh kelompok latihan berasal dari populasi yang berdistribusi nor-mal dan homogen, selanjutnya akan dilakukan pengujian hipotesis dengan menggunakan Uji Paired Sample T Test pada masing-masing kelompok latihan dan Uji One Way ANOVA untuk mengetahui perbedaan rata-rata (mean) 2 kelompok latihan yang berbeda.

Pengujian hipotesis ini dilakukan terhadap data tes awal (pretest) dan data tes akhir (posttest) keterampilan passing bawah bolavoli kelompok eksperimen de-ngan latihan distributed practice. Perhi-tungan uji hipotesis de-ngan menggunakan Uji Paired Sample $T$ Test. Hasil perhitungan uji hipotesis pada kelompok eksperimen dengan latihan distributed practice diperoleh nilai t-hitung sebesar $(-24,694)$ dengan nilai signifikasi sebesar $(0,000)$ yang berarti lebih kecil dari taraf signifikan 0,05 . Berdasarkan temuan tersebut maka hipotesis nihil $(\mathrm{HO})$ ditolak dan hipotesis alternatif $(\mathrm{Ha})$ diterima. De-ngan ini dapat disimpulkan bahwa ada pengaruh latihan distributed practice terhadap keterampilan passing bawah bolavoli pada peserta ekstrakurikuler bolavoli di SMA Negeri 10 Malang.

Pengujian hipotesis ini dilakukan terhadap data tes awal (pretest) dan data tes akhir (posttest) keterampilan passing bawah bolavoli kelompok kontrol dengan latihan konvensional. Perhitungan uji hipotesis dengan me-nggunakan Uji Paired Sample T Test. Hasil perhitungan uji hipotesis pada kelompok kontrol dengan latihan konvensional diperoleh nilai t-hitung sebesar ($17,804)$ dengan nilai sig-nifikasi sebesar $(0,000)$ yang berarti lebih kecil dari taraf signifikan 0,05 . Berdasarkan temuan tersebut maka hipotesis nihil $(\mathrm{H} 0)$ ditolak dan hipotesis alternatif $(\mathrm{Ha})$ diterima. Dengan ini dapat disimpulkan bahwa ada pe-ngaruh latihan konvensional terhadap keterampilan passing bawah bolavoli pada peserta ekstrakurikuler bolavoli di SMA Negeri 10 Malang.

Pengujian hipotesis dengan ana-lisis varians satu jalur dilakukan terha-dap data tes akhir (posttest) keterampilan passing bawah bolavoli kelompok eksperimen dengan latihan distributed practice dan data tes akhir (posttest) keterampilan passing bawah bolavoli kelompok kontrol dengan latihan konvensional. Perhitungan uji hipo-tesis dengan menggunakan One Way ANOVA. Hasil perhitungan uji hipotesis pada tes akhir (posttest) kelompok ekspe-rimen dengan latihan distributed practice dan kelompok kontrol dengan latihan konvensional diperoleh nilai signifikasi sebesar 0,562 > 0,05 . Ber-dasarkan temuan tersebut maka hipotesis nihil $(\mathrm{H} 0)$ diterima dan hipotesis alternatif $(\mathrm{Ha})$ ditolak. Dengan ini dapat dinyatakan bahwa tidak ada perbedaan pengaruh antara latihan distri-buted practice dan latihan konvensional terhadap keterampilan passing bawah bola-voli pada peserta ekstrakurikuler bolavoli di SMA Negeri 10 Malang.

Melihat dari rata-rata (mean) data test akhir (posttest) keterampilan passing bawah bolavoli kelompok latihan distributed practice yaitu sebesar 39,9 dan kelompok latihan konvensional sebesar 36,6 dan berdasarkan peningkatan persentase kemampuan kete-rampilan passing bawah bolavoli kelompok latihan distributed practice memiliki persentase peningkatan sebe-sar $42,5 \%$ yang lebih besar diban-dingkan persentase peningkatan kelompok latihan konvensional sebesar $26,2 \%$, dengan ini dapat disimpulkan bahwa latihan distributed practice memberikan pengaruh yang lebih baik daripada latihan konvensional terhadap peningkatan keterampilan passing bawah 
bolavoli bagi peserta ekstra-kurikuler bolavoli di SMA Negeri 10 Malang.

\section{PEMBAHASAN}

\section{Pengaruh Latihan Distributed Prac-tice Terhadap Keterampilan Passing Bawah Peserta Ekstrakurikuler Bola-voli SMA Negeri 10 Malang}

Berdasarkan hasil analisis penelitian bahwa terdapat pengaruh pemberian latihan distributed practice terhadap keterampilan passing bawah bolavoli pada peserta ekstrakurikuler bolavoli di SMA Negeri 10 Malang. Dalam perkembangannya metode latihan distributed practice sering diterap-kan ke cabang olahraga tertentu. Dalam cabang olahraga bolavoli, meto-de latihan ini dapat digunakan untuk meningkatkan keterampilan passing bawah bolavoli yang tentunya telah disesuaikan dengan kebutuhan.

Winarno (1994:8) mengemukakan bahwa "distributed practice adalah prinsip pengaturan giliran dalam latihan dimana diadakan pengaturan waktu untuk latihan dengan waktu untuk istirahat secara berselang-seling. Disini dipertimbangkan waktu untuk istirahat sama pentingnya dengan waktu untuk latihan". Latihan dengan distributed practice atau diselingi istirahat merupakan suatu bentuk atau metode latihan praktek latihan keterampilan olahraga yang dilakukan dalam waktu yang relatif singkat dan sering diselingi istirahat (Iskandar, 2011:43). Menurut Sugiyono (1996: 125) "Dasar latihan distributed practice adalah penggunaan selang istirahat (recovery) dari satu kegiatan ke kegiatan lain dilakukan dengan waktu yang agak panjang (kembali ke kondisi normal)". Distributed practice is theoretically difined as a series of spaced practices that includes several areas of practice during is each session (Murphree, 1971:9). Salah satu prinsip latihan juga menjadi faktor penting dalam pelaksanakan penerapan meto-de ini selama pemberian perlakuan ya-itu menurut Budiwanto (2012:26) men-jelaskan bahwa: "Pada waktu me-nyusun program latihan yang menyeluruh harus mencantumkan waktu pemulihan yang cukup. Apabila tidak memperhatikan waktu pemulihan ini, maka atlet akan mengalami kelelahan yang luar biasa dan berakibat pada sangat menu-runya penampilan. Jika pelatih memak-sakan memberi latihan yang sangat berat pada program latihan untuk beberapa waktu yang berurutan tanpa memberi kesempatan istirahat, maka kemungkinan terjadi kelelahan hebat (overtraining) atau terjadinya cidera".

Distributed practice mengutama-kan waktu untuk istirahat dalam pelaksanaanya, program latihan yang peneliti susun pada kelompok eksperimen dengan menggunakan latihan distributed practice ini sudah tercantum dalam program latihan yang dilakukan selama 6 minggu atau selama 16 kali pertemuan. Pada kelompok ini subjek berjumlah 10 peserta (6 peserta putra dan 4 peserta putri). Dalam penyu-sunan program latihan pada kelompok ini diberi program latihan dari peneliti yaitu diantaranya, latihan passing bawah gaya shadow, latihan melempar dan menangkap bola berpasangan, latihan passing dengan posisi jongkok dan berdiri, latihan melempar dan passing bawah berpasangan, latihan melempar dan passing bawah begerak ke kanan dan ke kiri, latihan passing bawah berpasangan, dan latihan passing bawah individu. Hal inilah yang mempengaruhi adanya pengaruh latihan distributed practice terhadap ke-terampilan passing bawah bolavoli pada peserta ekstrakurikuler bolavoli di SMA Negeri 10 Malang.

\section{Pengaruh Latihan Konvesional (Latihan Drill) Terhadap Keteram-pilan Passing Bawah Peserta Ekstra-kurikuler Bolavoli SMA Negeri 10 Malang}

Berdasarkan hasil analisis penelitian bahwa terdapat pengaruh pemberian latihan konvensional terhadap keterampilan passing bawah bolavoli pada peserta ekstrakurikuler bolavoli SMA Negeri 10 Malang. Perlakuan program latihan konvensional yang diberikan kepada kelompok kontrol ini sama seperti program latihan yang diberikan kepada kelompok eks-perimen yaitu dilakukan selama 6 minggu dengan 3 kali pertemuan setiap minggunya.

Program yang diterapkan pada latihan konvensional ini berupa latihan teknik yang dikombinasikan dengan latihan fisik. Program latihan ini mene-rapkan prinsip latihan padat atau latihan kontinyu secara terus menerus tanpa memberikan waktu istirahat 
Candra Junianto, Pengaruh Latihan Distributed Practice Terhadap Keterampilan Passing Bawah Bagi Peserta

disela-sela latihan yang hampir sama pula dengan metode latihan massed practice. Metode latihan kontinyu ada-lah metode yang di dalamnya mem-butuhkan waktu yang lama dan harus bertahap pengaruh latihan tidak dapat langsung diadaptasi secara mendadak untuk mencapai kemampuan maksimal. Pencapaian prestasi maksimal harus didukung oleh berbagai kemampuan dan keterampilan gerak (Azis, 2012: 29). Massed practice atau latihan padat merupakan prinsip pengaturan giliran praktek latihan keterampilan yang pelaksanaannya dilakukan secara terus menerus (Prabowo, 2012:26). Massed practice is theoretically defined as concentrated practice over a period of time in a specific area (Murphree, 1971: 9). Latihan yang dilakukan terus mene-rus tanpa diselingi istirahat akan ber-pengaruh terhadap kapasitas total paruparu dan volume jantung. Hal ini terjadi sebagai akibat adanya rang-sangan cukup berat diberikan terhadap sistem aerobik didalam tubuh (Riyanto, 2010:40).

Program latihan konvensional yang disusun dalam penelitian ini menitikberatkan pada pengulangan gerakan passing dengan frekuensi sebanyak-banyaknya sehingga pengu-asaan gerakanya akan lebih cepat tercapai dan otomatis. Pada kelompok ini subjek berjumlah 10 peserta (7 peserta putra dan 3 peserta putri). Dalam penyusunan program latihan pada kelom-pok ini diberi program latihan dari pelatih. Hal inilah yang mempengaruhi adanya pengaruh latihan konvensional terhadap keterampilan passing bawah bolavoli di SMA Negeri 10 Malang.

\section{Perbedaan Pengaruh Latihan Distri-buted Practice dan Latihan Konven-sional (Latihan Drill) Terhadap Kete-rampilan Passing Bawah Peserta Ekstra-kurikuler Bolavoli SMA Negeri 10 Malang}

Berdasarkan hasil analisis pene-litian bahwa tidak terdapat perbedaan pengaruh antara pemberian latihan distributed practice dan latihan konvensional terhadap keterampilan passing bawah bolavoli pada peserta ekstra-kurikuler bolavoli di SMA Negeri 10 Malang. Jika dilihat dari perolehan nilai rata-rata (mean) kedua kelompok latihan dan dari persentase peningkatan kelompok latihan distributed practice memiliki peningkatan sebesar $42,5 \%$ dan kelompok latihan konven-sional memiliki peningkatan sebesar $26,2 \%$ ternyata kelompok latihan distri-buted practice memiliki kecenderungan lebih baik mengalami peningkatan terhadap keterampilan passing bawah bolavoli daripada kelompok latihan konvensional.

Adanya kecenderungan pening-katan keterampilan passing bawah bolavoli pada kelompok yang diberi perlakuan latihan distributed practice dimungkinkan karena pengaruh adanya waktu untuk istirahat disela proses latihan. Metode latihan tersebut juga memiliki keunggulan diantaranya dapat meminimalisir terjadinya cidera karena tidak melakukan proses latihan dengan porsi yang terus-menerus sehingga juga dapat terhindar dari kelelahan. Selain itu pemberian waktu istirahat disela proses latihan juga dimaksudkan untuk memberikan evaluasi kepada atlet sehingga gerakan-gerakan latihan yang sebelumnya telah dilakukan bisa dikoreksi dimana letak kesalahannya dan secara bersamaan bisa diperbaiki diwaktu istirahat tersebut agar diwaktu latihan berikutnya bisa diminimalisir terjadinya kesalahan yang sama. Pada latihan konvensional pemberian latihan atau perlakuan selama penelitian tedapat bentuk kombinasi latihan teknik dan latihan fisik. Pemberian kombinasi latihan pembentukan fisik pada pro-gram latihan konvensional dimak-sudkan untuk meningkatkan kemampuan dan potensi atlet. Selain itu dalam pemberian latihan teknik program latihan yang disusun pada kelompok konvensional ini memiliki porsi beban latihan yang berlebihan dengan memberikan beban latihan secara terus-menerus tanpa memperhatikan prinsip interval atau pemberian waktu istirahat sehingga dimungkinkan kua-litas peningkatan keterampilan atlet menjadi menurun karena mengalami adaptasi latihan secara berlebihan.

Penelitian sebelumnya telah dilakukan oleh Iskandar (2011:36), yaitu: "Perbedaan Pengaruh Metode Massed Practice Dengan Distributed Practice Terhadap Kemampuan Pass Atas Bolavoli Yunior Klub Bolavoli Rinex Boyolali. Hasil penelitian menunjukkan bahwa latihan distributed practice lebih baik daripada latihan massed practice terhadap kemampuan pass atas bolavoli pada pemain Yunior Klub Bolavoli Rinex 
Boyolali. Hasil analisis dalam penelitian ini me-nunjukkan bahwa latihan distributed practice lebih baik daripada latihan massed practice terhadap kemampuan pass atas bolavoli pada pemain Yunior Klub Bolavoli Rinex Boyolali. Latihan distributed practice memiliki pe-ningkatan sebesar 33,33\% lebih baik dari hasil latihan massed practice yang memiliki peningkatan sebesar 24, 468\%". Kemudian penelitian selanjut-nya yang dilakukan oleh Marwan (2009:125), yaitu: "Perbedaan Metode Latihan Distribusi, Latihan Padat dan Motivasi Berprestasi Terhadap Kete-rampilan Bolavoli. Hasil penelitian menun-jukkan bahwa latihan distribusi lebih baik daripada yang dilatih dengan latihan padat. Hal ini karena rerata keterampilan bolavoli bagi siswa dengan skor motivasi berprestasi rendah yang dilatih menggunakan latihan padat adalah sebesar 38,30 dan simpangan baku 10,44 lebih tinggi namun tidak berarti dibandingkan dengan latihan distribusi yaitu sebesar 35,80 dan simpangan baku 7,66. Dengan kata lain keterampilan bolavoli baik yang dilatih dengan latihan distribusi mau-pun latihan padat sama baiknya bagi kelompok siswa yang memiliki motivasi ber-prestasi rendah".

Pada penelitian ini membahas mengenai pengaruh latihan distributed practice terhadap keterampilan passing bawah bagi peserta ekstrakurikuler bolavoli SMA Negeri 10 Malang. Penelitian ini memiliki persamaan dengan penelitian terdahulu yaitu sama-sama membahas mengenai penelitian eksperimen penerapan me-tode latihan distributed practice, tetapi pada penelitian ini variabel bebasnya hanya menggunakan latihan distributed practice dan untuk variabel terikatnya yaitu keteram-pilan passing bawah permainan bolavoli. Hal inilah yang mempengaruhi adanya perbedaan pengaruh antara latihan distributed practice dan latihan konven-sional terhadap keterampilan passing bawah bolavoli pada peserta ekstrakurikuler bolavoli di SMA Negeri 10 Malang. Dengan demikian, jika dilihat dari skor rata-rata (mean) dan dari persentase pening-katan keterampilan passing bawah bolavoli hasil dari penelitian ini me-nunjukkan bahwa metode latihan distributed practice memiliki pengaruh yang lebih baik daripada metode latihan konvensional terhadap keterampilan passing bawah bolavoli peserta ekstrakurikuler bolavoli di SMA Negeri 10 Malang.

\section{KESIMPULAN}

Berdasarkan hasil penelitian dan hasil analisis data yang telah dilakukan, maka dapat disimpulkan bahwa: (1) Terdapat pengaruh latihan distributed practice terhadap keterampilan passing bawah bolavoli pada peserta eks-trakurikuler bolavoli SMA Negeri 10 Malang. (2) Terdapat pengaruh latihan konvensional terhadap keterampilan passing bawah bolavoli pada peserta ekstrakurikuler bolavoli SMA Negeri 10 Malang. (3) Tidak terdapat perbedaan pengaruh antara latihan distributed practice dan latihan konvensional ter-hadap keterampilan passing bawah bolavoli pada peserta ekstrakurikuler bolavoli SMA Negeri 10 Malang.

\section{SARAN}

Berdasarkan hasil penelitian dan pembahasan ini, maka peneliti bermaksud ingin menyampaikan saran-saran yang nantinya penelitian ini bisa bermanfaat bagi banyak pihak, diantaranya: (1) Bagi pelatih dapat menggunakan metode latihan distributed practice ataupun metode latihan kontinyu sebagai referensi bentuk latih-an untuk meningkatkan keterampilan khususnya keterampilan passing ba-wah bolavoli. (2) Bagi pemain bolavoli dapat menjadikan hasil penelitian ini sebagai pedoman dan acuan dalam latihan tambahan guna meningkatkan keterampilan passing bawah bolavoli. (3) Bagi peneliti lain hendaknya mencermati penelitian sebelumnya sehingga dalam menentukan atau mem-buat program sesuai dengan ranca-ngan yang diinginkan.

\section{DAFTAR RUJUKAN}

Ahmadi, N. 2007. Panduan Olahraga Bola Voli. Solo: Era Pustaka Utama. 
Candra Junianto, Pengaruh Latihan Distributed Practice Terhadap Keterampilan Passing Bawah Bagi Peserta

Azis, A. 2012. Pengaruh Latihan Metode Kontinyu dan Metode Interval Terhadap Kemampuan Passing Atas Bolavoli Peserta Ekstrakurikuler Siswa Kelas VII SMPN 3 Pakis Magelang Tahun 2012. Universitas Negeri Yogyakarta, (Online), (http://eprints.uny.ac.id/ 7598/5/Lampiran- 08601241030. pdf),diakses tanggal 18 Juli 2016.

Budiwanto, S. 2012.Metodologi Latihan Olahraga.Malang: Universitas Negeri Malang (UM Press).

Durrwachter, G. 1982. Bola Volley Belajar dan Berlatih Sambil Bermain. Jakarta: PT. Gramedia Jakarta.

Hadi, Sutrisno. 2004. Statistik. Bandung: ANDI.

Irianto, A. 2012. Statistik Konsep Dasar, Aplikasi, \& Pengembangannya. Jakarta: Kencana Prenada Media Group.

Iskandar, M. 2011. Perbedaan Pengaruh Metode Massed Practice Dengan Distributed Practice Terhadap Kemampuan Pass Atas Bolavoli Yunior Klub Bolavoli Rinex Boyolali. Jurnal IImiah Spirit, 11 (1), (Online), (http://ejournal.utp. ac.id/index.php/JIS/article/view/40) , diakses 30 Juni 2016.

Lutan, R. 1988. Belajar Keterampilan Motorik, Pengantar Teori dan Metode. Jakarta: Departemen Pendidikan dan Kebudayaan Direktorat Jenderal Pendidikan Tinggi Proyek Pengembangan Lembaga Pendidikan Tenaga Kependidikan.

Maksum, A. 2012. Metodologi Penelitian dalam Olahraga. Surabaya: Unesa University Press.

Marwan, I. 2009. Pengaruh Metode Latihan Distribusi, Latihan Padat dan Motivasi Berprestasi Terhadap Keterampilan Bolavoli. Universitas Siliwangi. (Online), (https://www. google.co.id/url?sa=t\&rct=j\&q=\&es $\mathrm{rc}=\mathrm{s} \&$ source $=$ web\& $\mathrm{cd}=3 \& \mathrm{cad}=\mathrm{rja}$ \&uact $=8 \&$ ved $=0$ ahUKEwiSwYL8lc NAhUMQI8KHVkpAB8QFggpMA I\&url=http\%3A\%2F\%2Fforumkepe ndidikan.unsri.ac.id\%2Fuserfiles\% 2FArtikel\%2520lis\%2520MarwanULSliOKE.pdf\&usg=AFQjCNHRf 1 TbwtOEgmeGgt3c6XxOfaqHGQ\& bvm=bv.125801520,d.c2l), diakses 30 Juni 2016.

Mu'arifin. 2009. Dasar-dasar Pendidikan Jasmani dan Olahraga. Malang: Universitas Negeri Malang (UM Press).

Murphree, T. 1971. Effects Of Massed Practice And Distributed Practice Upon Motor Learning And Retention Of A Novel Gross Motor Task. North Texas State University in Partial Filfilment of the Requirements, (Online), (http://digital.library.unt.edu./ark:/6 7531/metadc164491), diakses tanggal 18 Juli 2016.

Prabowo, F. 2012. Perbedaan Pengaruh Latihan Dengan Metode Distributed Practice dan Massed Practice Terhadap Kemampuan Pukulan Backhand Tenis Meja Pada Atlet Pemula Putra PTM PMS Surakarta Tahun 2011. Universitas Sebelas Maret Surakarta, (Online), (http://dglib. uns.ac.id/ dokumen/detail/25623/ Perbedaan-Pengaruh- Latihandengan Metode -DistributedPractice-dan-Massed-PracticeTerhadap-KemampuanPukulanBackhand-Tenis-MejaPada-Atlet-Pemula-Putra - PTM PMS - Surakarta Tahun-2011.pdf), diakses tanggal 18 Juli 2016.

Prihatin, E. 2011. Manajemen Peserta Didik. Bandung: Alfabeta.

Riyanto, S. 2010. Perbedaan Pengaruh Latihan Dengan Metode Distributed Practice dan Massed Practice Terhadap Kemampuan Pukulan Forehand Pada 


\begin{abstract}
Mahasiswa Putra Pembinaan Prestasi Tenis Meja JPOK FKIP UNS 2009/2010. Universitas Sebelas Maret Surakarta, (Online), (https:// webcache.googleusercontent.com/ search?q=cache:yVMT4IVzH3gJ:h ttps://digilib.uns.ac.id/dokumen/do wnload/13705/MjgzOTA\%3D/

Perbedaan- pengaruh latihan dengan- metode-distributed practice- dan-massed -practiceterhadap-kemampuan-pukulanforehand-pada -mahasiswa- putrapembinaan-prestasi-tenis-mejaJPOK -FKIP -UNS- 20092010abstrak.pdf $+\& c d=1 \&$ hl=id\&ct=clnk $\& g \mathrm{l}=\mathrm{id})$, diakses tanggal 18 Juli 2016.
\end{abstract}

Roesdiyanto. 1991. Strategi dan Taktik Permainan Bola Voli. Malang: Departemen Pendidikan dan Kebudayaan IKIP Malang Proyek Operasi dan Perawatan Fasilitas.

Sugiyono, I. 1996. Sejarah, Teknik, Strategi dan Metode Permainan Bola Voli. Malang: Departemen Pendidikan dan Kebudayaan IKIP Malang Proyek Operasi dan Perawatan Fasilitas Proyek IKIP Malang.

Suharno. 1991. Pedoman Pelatihan Bolavoli. Yogyakarta: Tanpa Penerbit.

Winarno dan Sugiyono, I. 2011. Sejarah dan Teknik Dasar Permainan Bolavoli. Malang: Fakultas IImu Keolahragaan Universitas Negeri Malang.

Winarno. 1994. Belajar Motorik.Malang: Departemen Pendidikan dan Kebudayaan IKIP Malang Proyek Operasi dan Perawatan Fasilitas.

Winarno. 2007. Metodologi Penelitian dalam Pendidikan Jasmani. Malang: Fakultas IImu Pendidikan Universitas Negeri Malang.
Yunus, M. 1992. Olahraga Pilihan Bola Voli. (tanpa kota tempat penerbitan): Departemen Pendidikan dan Kebudayaan Direktorat Jendral Pendidikan Tinggi Proyek Pembinaan Tenaga Kependidikan. 